\title{
CHROMATOGRAPHIC ANALYSIS OF 6-GINGEROL AND 6-SHOGAOL USING TLC AND HPLC METHODS
}

\author{
(C) R. Jazokaite, M. Marksa, A. Zevzikoviene, A. Zevzikovas
}

\begin{abstract}
В даний час деякі види рослин відомі не тільки своӥм смаком і ароматом, але $і$ своєю лікарської иінністю. Імбир аптечний (сімейство Імбирні) містить ряд біологічно активних фенольних компонентів, які в чистому вигляді або його похідних можуть бути потенщійними антиоксидантами, в більшості випадків вчені виявляють 6-гынгерол і 6-цогаол в якості основних компонентів кореневищ імбиру.

Методи. Для иьього дослідження ми вибрали чотири різні харчові добавки, щуо містять імбир і один народний рослинний лікарський засіб. Присутність двох основних складових імбиру в досліджуваних об'єктах аналізували за допомогою ТШХ аналізу, який виконували з використанням CAMAG TLC Visualizer, іншим методом була ВЕРХ, для якої потрібна високоефективна рідинна хроматографічна система Waters 2695 з фотодіодних детектором Waters 966 PDA.

Результати. Наші результати показують, щзо харчові добавки і лікарські препарати, що містять імбир, містять два основних компоненти, які забезпечують біологічно активні властивості імбиру. Хроматографічний аналіз може бути корисний для отримання інформацї̈ про якість кореневищ імбиру $i$ комериійних імбирних продуктів.
\end{abstract}

Висновки. Обрані методи хроматографії підходять для якісної $і$ кількісної оцінки 6-гынгерола $i$ 6шогаола в харчових добавках та інших продуктах

Ключові слова: імбир, Zingiber officinale, ТШХ, тонкошарова хроматографія, ВЕРХ, високоефективна рідинна хроматографія, харчові добавки, якісний аналіз, кількісний аналіз

\section{Introduction}

Ginger (Zingiber officinale Roscoe) is the most widely cultivated and used spice around the globe next to the black pepper.

Ginger has gained considerable attention in developed countries in recent years, especially for it's use in the treatment of conditions such as nausea of motion sickness, loss of appetite, indigestion, common cold and other ailments $[1,2]$.

\section{Formulation of the problem}

Gingerols and shogaols, pungent principles of ginger, are biologically active components that make a significant contribution towards the medicinal applications of ginger. Quality evaluation of the herbal products is a fundamental requirement before releasing it into the market [3, 4].

\section{Analysis of recent studies and publications}

Over the past years, interest in the research for new natural antioxidants has grown, because plants are full of phenolic compounds which have antioxidant potency. The antioxidant activity of $Z$. officinale R. rhizome extracts might be due to their phenolic compounds such as 6-gingerol and 6-shogaol.

These two constituents are mainly found in other scientific works and scientists strongly believe, that 6gingerol and 6-shogaol are responsible for biological ginger activity.

Ginger also was reported to has not only antioxidant activity, but also antimicrobical, antifungal, anticancer and anti-inflammatory activities [5, 6].

\section{Allocation of unsolved parts of the general problem}

To the best of our knowledge, so far there was very limited reports on TLC and HPLC analysis of Lithuania's food supplements, containing ginger. There were reported some research work from other countries with commonly used water and ethanol as a solvents for extraction of phenolic compounds of ginger, but not many analysis were applied using methanol as a solvent. For comparison in our study we qualitatively and quantitatively analyzed two major component of ginger rhizomes by using methanol as a solvent to prepare test sample's extracts $[3,7]$.

\section{Formulation of goals (tasks) of article}

It is very important to apply easy to implement analytical techniques for the pharmaceutical industry in order to save time and finance resources during daily routine laboratory tests. Also, if manufacturers are going to use ginger rhizome's powder or extract in their dietary supplements or other commercial procucts, the composition of its major components must be determined and standardized.

The aim of this research is to analyse the major constituents of ginger using high-performance liquid chromatography (HPLC) and thin-layer chromatography (TLC).

\section{Materials and methods}

The object of investigation: we have investigated four different multivariate food supplements from Lithuania's community pharmacies (FS_1, FS 2, FS 3, FS_4), containing ginger as the main component in the 
composition and one traditional herbal medicine containing ginger rhizome powder and a small amount of addi- tional substances, which was also on Lithuania's medicine's market (THM_1). (Table 1)

Table 1

Investigated food supplements

\begin{tabular}{|l|c|c|c|}
\hline The object of investigation & Pharmaceutical form & The amount of ginger & Country of origin \\
\hline FS_1 & Tablets & $300 \mathrm{mg}$ (in one tablet) & Denmark \\
\hline FS_2 & Tablets & $300 \mathrm{mg}$ (in one tablet) & Denmark \\
\hline FS_3 & Tablets & $300 \mathrm{mg}$ (in one tablet) & Poland \\
\hline FS_4 & Tablets & $50 \mathrm{mg}$ (in one tablet) & Lithuania \\
\hline THM_1 & Hard capsules & $250 \mathrm{mg}$ (in one capsule) & Poland \\
\hline
\end{tabular}

Reference and test solutions:

For the thin-layer chromatography we prepared test solutions following European Pharmacopoeia 9.0 and other author's researches, so the routine to all test samples were the same, we added $5 \mathrm{ml}$ of methanol to $1,0 \mathrm{~g}$ of the powdered tablet or capsule and shaked for 15 minutes, after that we filtered all the samples. For the high-performance liquid chromatography we prepared test solutions following other author's researches, so all solutions were prepared by taking $2,5 \mathrm{mg}$ powdered tablet or capsule substance and $25 \mathrm{ml}$ of methanol was added to the flask, after that the test solutions were extracted in ultrasonic bath for $60 \mathrm{~min}$. Reference solutions of 6-gingerol and 6-shogaol were prepared with methanol using both substance's standards $[4,8]$.

TLC Methodology: analysis was performed using TLC Silica Gel 60 F254 glass plates (Sigma-Aldrich, Germany). Food supplement's and standard's samples were applied on the chromatographic plates using semiautomatic sampling applicator CAMAG Linomat-5. Retention values of the test solutions were determined using visualization device CAMAG TLC Visualizer. Solvent system was hexane:ether (40:60 V/V) and we used $366 \mathrm{~nm}$ and white light for visualization. The plates were dried in air and spots were detected using a spray with a $10 \mathrm{~g} / \mathrm{L}$ solution of vanilin in sulfuric acid, and examined in daylight while heating at $100-105{ }^{\circ} \mathrm{C}$ for 10 minutes $[3,8]$.

HPLC Methodology: analysis was performed using The Waters Alliance 2695 Separations Module (a high performance liquid chromatographic system) with an auto-injector sampler programmed at $10 \mu \mathrm{l}$ capacity per injection. Chromatographic separations were performed on ACE C18 column (250x4,6 mm). The separation was performed with a mobile phase consisting of acetonitrile and water (Table 2) [9-11].

Table 2

Mobile phase exchange stages

\begin{tabular}{|l|c|c|c|c|c|}
\hline \multicolumn{1}{|c|}{ Time } & $0 \mathrm{~min}$. & $0-8 \mathrm{~min}$. & $8-17 \mathrm{~min}$. & $17-32 \mathrm{~min}$. & $32-43 \mathrm{~min}$. \\
\hline Acetonitrile & $55 \%$ & $50 \%$ & $35 \%$ & $0 \%$ & $55 \%$ \\
\hline Water & $45 \%$ & $50 \%$ & $65 \%$ & $100 \%$ & $45 \%$ \\
\hline
\end{tabular}

Chromatographic run time was $43 \mathrm{~min}$. The temperature was $25{ }^{\circ} \mathrm{C}$ with a flow-rate od $1 \mathrm{ml} / \mathrm{min}$ and after all - chromatograms were monitored at $255 \mathrm{~nm}$. Data analysis and other operations were controlled using the Empower2 (Empower Chromatography Data Software). [10]

Analysis of food supplements: qualitative and quantitative analysis was performed under the above mentioned conditions. For qualitative analysis $20 \mu \mathrm{l}$ of each test solution was applied on the chromatographic plates. For quantitative evaluation calibration curve of 6gingerol was obtained using 9 prepared reference solutions, which concentrations were between 0,000883 $\mathrm{mg} / \mathrm{ml}$ and $0,226 \mathrm{mg} / \mathrm{ml}$. The experiment was carried out at triplicate. The values were expressed as Mean \pm Standard deviation. Also, the next calibration curve of 6-shogaol was obtained using 6 prepared reference solutions, which concentrations were between $0,0125 \mathrm{mg} / \mathrm{ml}$ and $0,4 \mathrm{mg} / \mathrm{ml}$. The data were collected and analyzed using ,Microsoft Excel 2010“ (Microsoft, JAV) $[1,10,11]$

\section{Results}

Thin-layer chromatography (TLC) was used to identify the principle ginger compunds: 6-gingerol and 6-shogaol. Chromatograms for ginger-containing commercial products was developed using a mobile phase hexane:ether (40:60) and the plates were sprayed with detection reagent. TLC fingerprints developed for the food supplements and traditional herbal medicine showed well-defined zones throughout and clear definition of the pungent principles characteristic of ginger between $R_{f}$ values of 0,73 and 0,91 (Table 3)

Chromatograms of ginger products qualitatively revealed of the presence of 6-gingerol and 6-shogaol on TLC Silica plates under CAMAG TLC Scanner captured at white light (Fig. 1). The fingerprint of the test solution was similar to test samples prepared from food supplements (B-E) and traditional herbal medicine $(\mathrm{F})$.

Chromatograms under the same scanner captured at $366 \mathrm{~nm}$ light also qualitatively revealed of the presence of 6-gingerol and 6-shogaol (Fig. 2). In this case, we can clearly see that the intensity of the colors help us to identify the main differences between samples.

Using the data software system winCATS we calculated retention factor $\left(\mathrm{R}_{\mathrm{f}}\right)$ and standard deviation (SD) of all the samples (Table 3 ). 


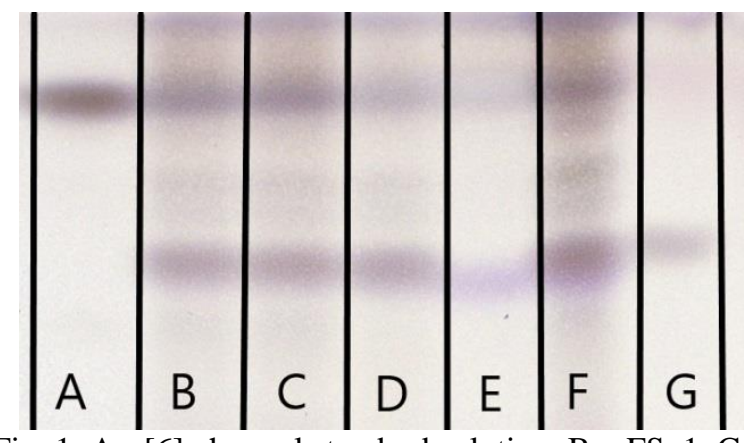

Fig. 1. A - [6]-shogaol standard solution, B - FS_1, C FD_2, D - FS_3, E - FD_4, F - THM_1, G- [6]-gingerol standard solution.

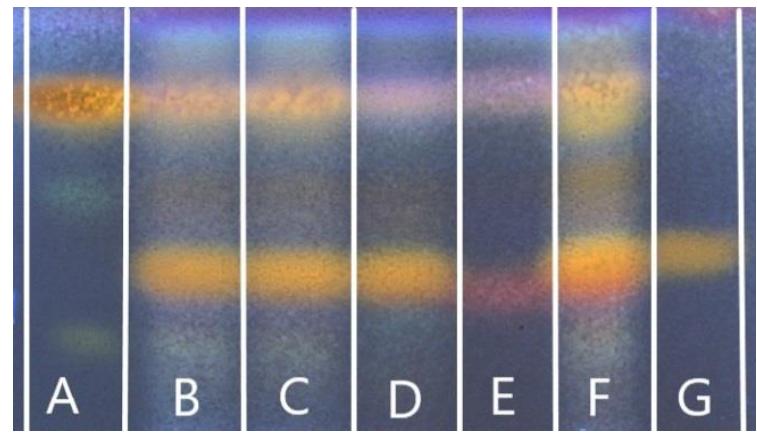

Fig. 2. A- [6]-shogaol standard solution, B -

FS_1, C - FD_2, D - FS_3, E-FD_4, F - THM_1, G-

[6]-gingerol standard solution.

Table 3

Investigated object's retention times and standard deviation

\begin{tabular}{|c|c|c|c|c|}
\hline $\begin{array}{c}\text { Test sam- } \\
\text { ple }\end{array}$ & $\begin{array}{c}\text { 6-gingerol R } \mathrm{f} \text { aver- } \\
\text { age }\end{array}$ & $\begin{array}{c}\text { 6-gingerol standard devia- } \\
\text { tion }\end{array}$ & $\begin{array}{c}\text { 6-shogaol } \mathrm{R}_{\mathrm{f}} \text { aver- } \\
\text { age }\end{array}$ & $\begin{array}{c}\text { 6-shogaol standard devia- } \\
\text { tion }\end{array}$ \\
\hline FS_1 & 0.75 & 0.002 & 0.90 & 0.001 \\
\hline FS_2 & 0.75 & 0.001 & 0.90 & 0.001 \\
\hline FS_3 & 0.74 & 0.001 & 0.90 & 0.002 \\
\hline FS_4 & 0.73 & 0.002 & 0.90 & 0.002 \\
\hline THM_1 & 0.76 & 0.001 & 0.91 & 0.001 \\
\hline
\end{tabular}

This method is suitable for the analysis of 6gingerol and 6-shogaol composition in a wide variety of ginger-containing dietary supplements and other commercials products. Nowadays TLC technique has gained much popularity for standardization of the herbal formulations due to analysis of several samples simultaneously with small quantity of marker compound and mobile phase with a very less time [2, 5].

High-performance liquid chromatography (HPLC) was used to identify 6-gingerol and 6-shogaol qualitatively and quantitatively. The 6-gingerol and 6-shogaol peak identifications were based on the retention times of the standards and further confirmed by comparing their photodiode array spectra to those of the individual standards. (Fig. 3-5).
According to the chromatogram, we can clearly see that 6-gingerol showed retention time at $10,874 \mathrm{~min}$ and 6-shogaol showed retention time at $19,934 \mathrm{~min}$.

The chromatogram shows that 6-gingerol retention time in the FS_2 sample was 10,871, which is very similar to FS_1 results and 6-shogaol retention time of the second food supplement was also resembling the first food supplement with a meaning of 19,931 min. Also, we discovered very familiar data of the third food supplement.

The qualitative analysis of the fourth food supplement was productive despite the fact that later quantitative analysis showed the lowest amount of biological active substances in this sample (Fig. 5,7).

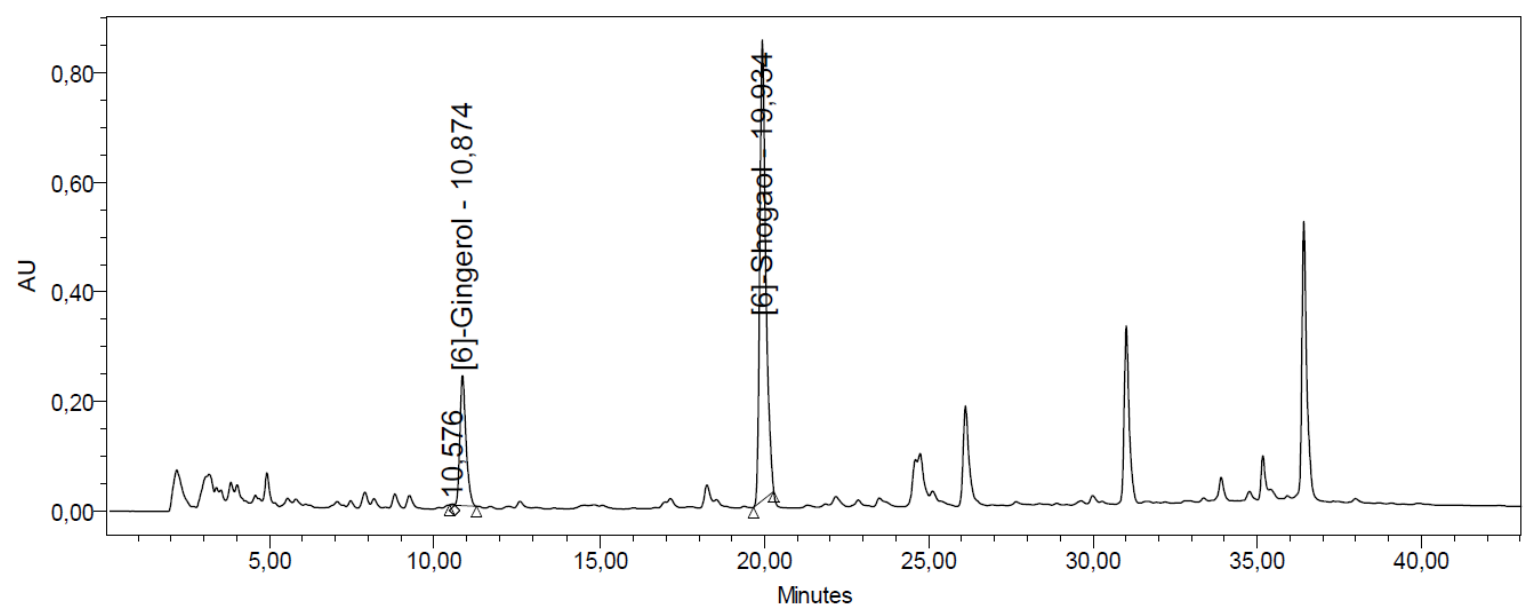

Fig. 3. The first food supplement's (FS_1) chromatogram 


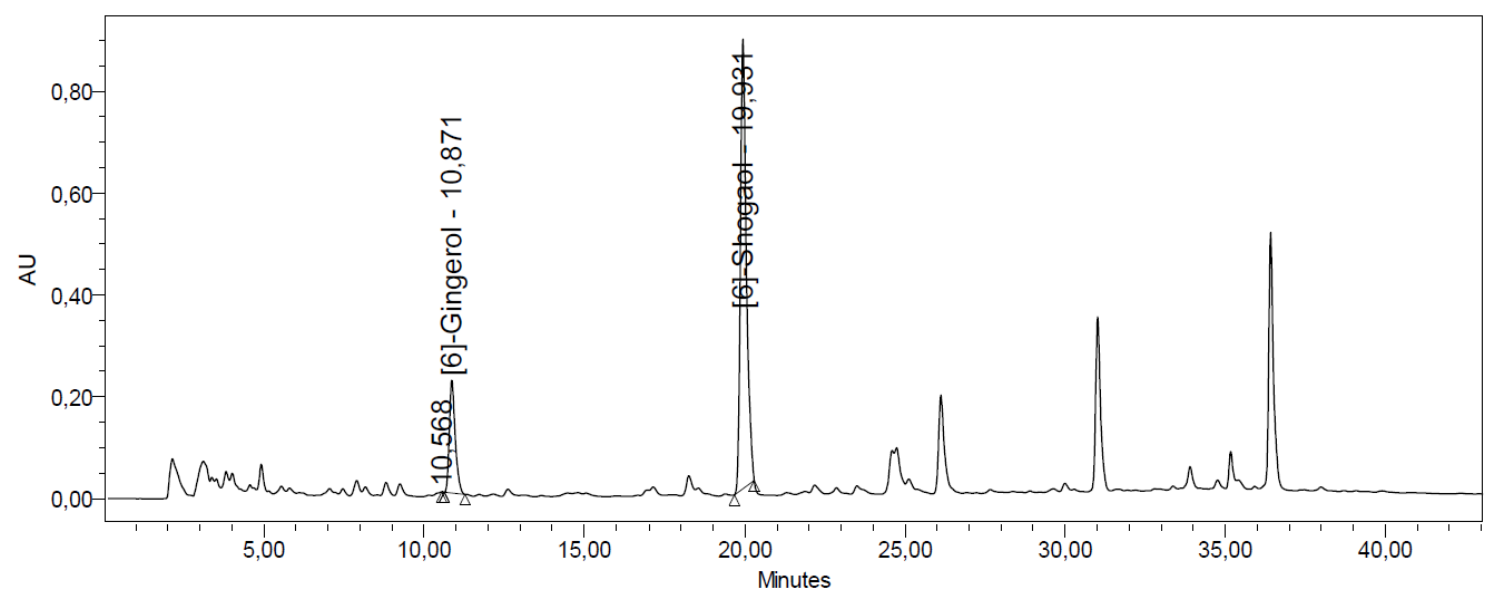

Fig. 4. The second food supplement`s (FS_2) chromatogram

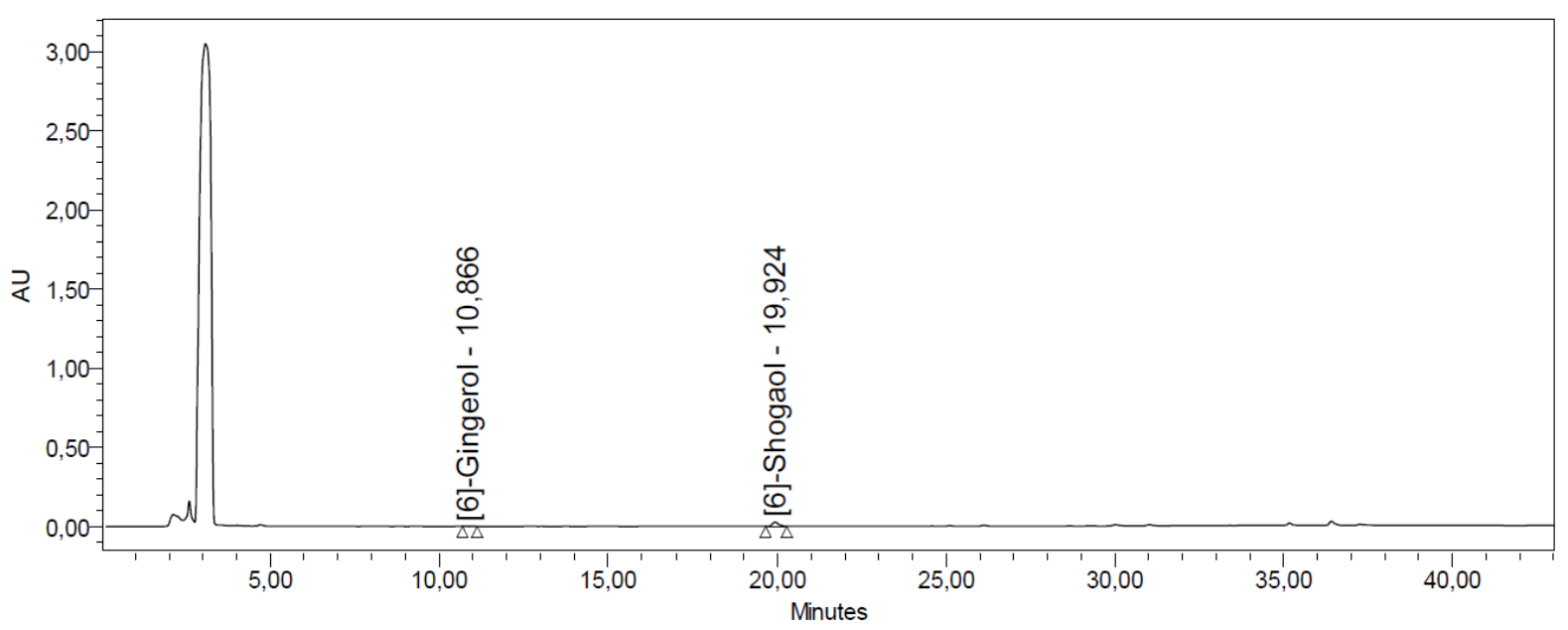

Fig. 5. The fourth food supplement's (FS_4) chromatogram

We found out 6-gingerol retention time at 10,866 min. and 6-shogaol retention time at 19,924 min. For comparison we investigated traditional herbal medicine's sample, which showed us very similar results (Fig. 6).

By looking at the peaks we can see that 1 'st number is 6-gingerol with a retention time of 10,867 $\mathrm{min}$ and the second number in the chromatogram (2) is 6-shogaol with a retention time of $19,921 \mathrm{~min}$. These retention times are very similar to standard's and food supplements retention times.

The 6-gingerol and 6-shogaol were quantitated using external standards (Fig. 7).

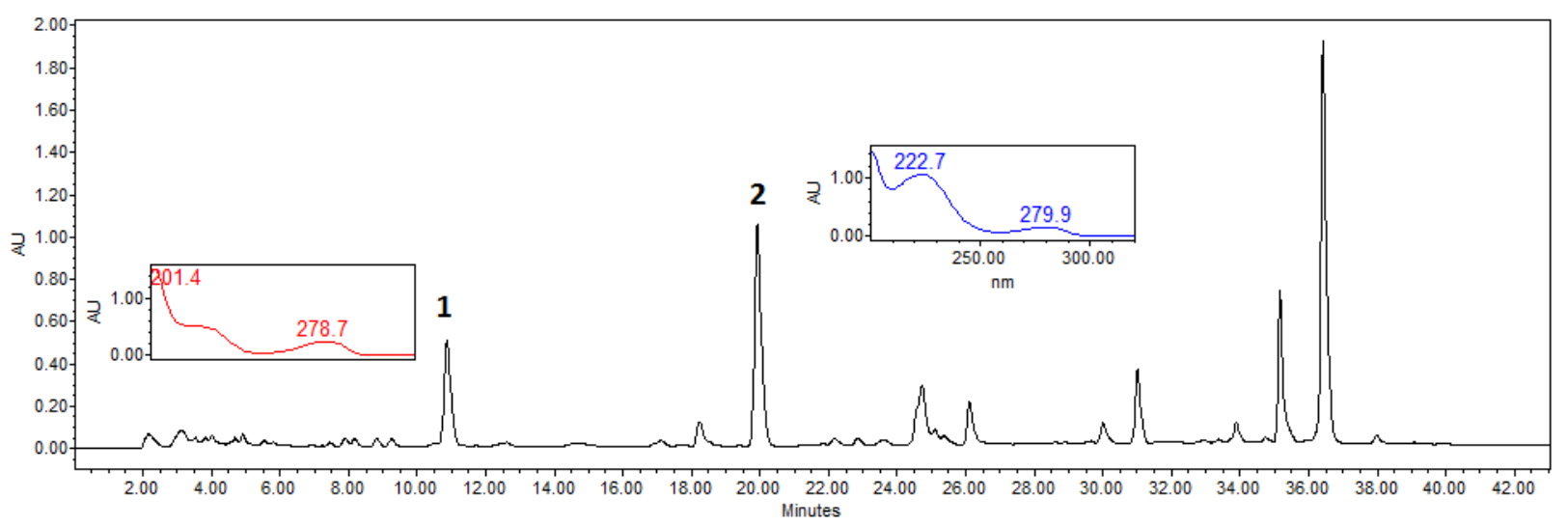

Fig. 6. The chromatogram of traditional herbal medicine (THM_1) 


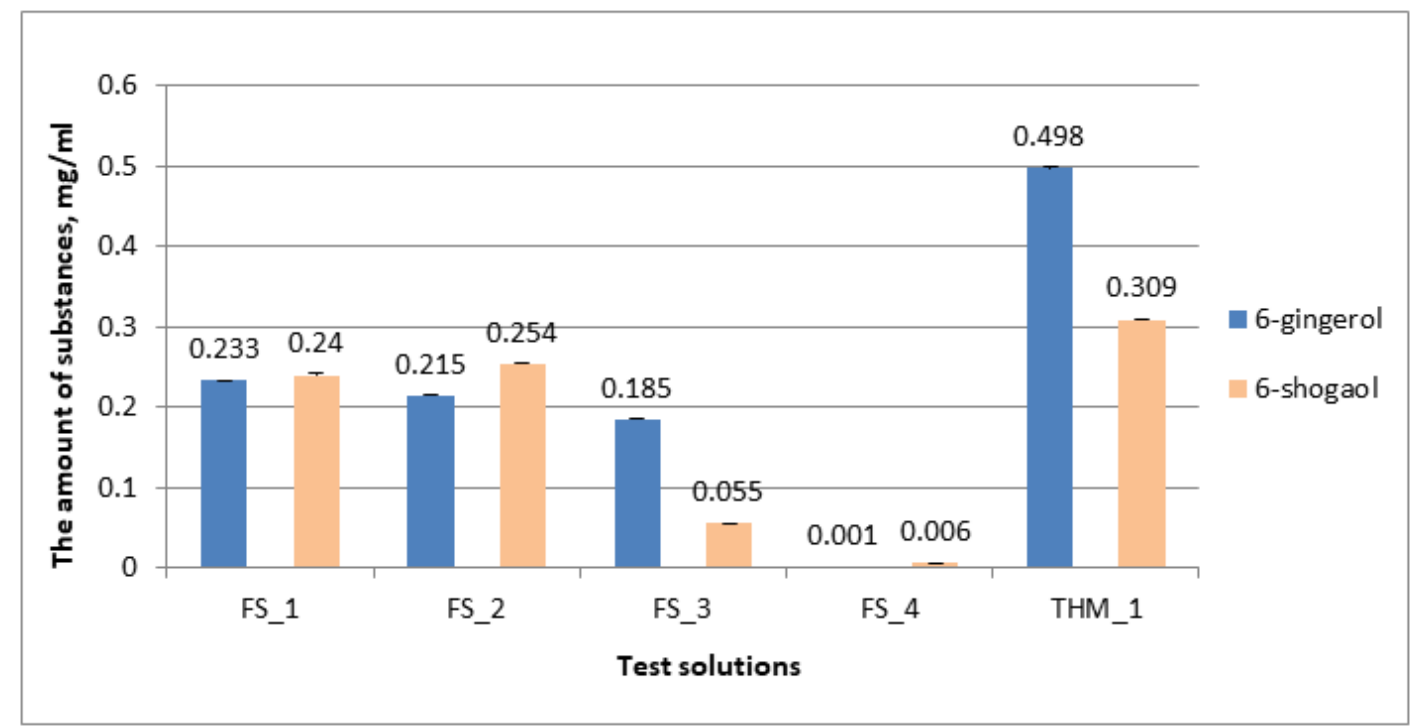

Fig. 7. 6-gingerol and 6-shogaol composition of various test samples

The 6-shogaol concentration in the FS_1, FS_2 and FS_4 test samples was found to be higher than that of 6-gingerol. Otherwise, we found that in traditional herbal drug 6-gingerol concentration was 1.6 times higher than 6-shogaol. Across brands, the concentrations of principal constituents varied widely.

On average, the largest amount of active substances contained FS $2(0,215 \pm 0,001 \mathrm{mg} / \mathrm{ml}$ of 6 gingerol and $0,254 \pm 0,002 \mathrm{mg} / \mathrm{ml}$ of 6 -shogaol) food supplement and traditional herbal medicine $(0,498 \pm 0,001 \mathrm{mg} / \mathrm{ml}$ of 6 -gingerol and $0,309 \pm 0,001$ $\mathrm{mg} / \mathrm{ml}$ of 6 -shogaol) respectively. It is important to mention that the largest amount of biological active substances is this research was found in the test object, which contained $250 \mathrm{mg}$ ginger rhizomes. This result might be due to the tandartization and mandatory qual- ity control of the medicine before releasing it into the market.

\section{Conclusions}

1. The developed TLC and HPLC methods was found to be accurate, reproducible and might be applicable to the analysis of other commercial ginger products and medicines.

2. 6-gingerol and 6-shogaol were analyzed qualitatively and quantitatively in four food supplements and one traditional herbal medicine. Active components were identified qualitatively using both TLC and HPLC methods. For quantity evaluation only HPLC method was chosen.

3. HPLC is a common method of analysis for the pungent principles of ginger, but TLC is a far economical technique, considering both time and resources.

\section{References}

1. Kubra I. R., Rao L. J. M. An Impression on Current Developments in the Technology, Chemistry, and Biological Activities of Ginger (Zingiber officinaleRoscoe) // Critical Reviews in Food Science and Nutrition. 2012. Vol. 52, Issue 8. P. 651688. doi: http://doi.org/10.1080/10408398.2010.505689

2. Chemical and antioxidant parameters of dried forms of ginger rhizomes / Jelled A., Fernandes A., Barros L., Chahdoura H., Achour L., Ferreira I. C. F. R., Cheikh H. B. // Industrial Crops and Products. 2015. Vol. 77. P. 30-35. doi: http://doi.org/10.1016/j.indcrop.2015.08.052

3. Alam P. Densitometric HPTLC analysis of 8-gingerol in Zingiber officinale extract and ginger-containing dietary supplements, teas and commercial creams // Asian Pacific Journal of Tropical Biomedicine. 2013. Vol. 3, Issue 8. P. 634-638. doi: http://doi.org/10.1016/s2221-1691(13)60128-8

4. An approach towards optimization of the extraction of polyphenolic antioxidants from ginger (Zingiber officinale) / Mukherjee S., Mandal N., Dey A., Mondal B. // Journal of Food Science and Technology. 2012. Vol. 51, Issue 11. P. 3301-3308. doi: http://doi.org/10.1007/s13197-012-0848-z

5. Patel D. K., Dhanabal S. P. Development of bioanalytical parameters for the standardization of Zingiber officinale // Journal of Acute Disease. 2013. Vol. 2, Issue 2. P. 134-136. doi: http://doi.org/10.1016/s2221-6189(13)60113-4

6. Characterisation of cultivars of Jamaican ginger (Zingiber officinale Roscoe) by HPTLC and HPLC / Salmon C. N. A., Bailey-Shaw Y. A., Hibbert S., Green C., Smith A. M., Williams L. A. D. // Food Chemistry. 2012. Vol. 131, Issue 4. P. $1517-1522$. doi: http://doi.org/10.1016/j.foodchem.2011.09.115

7. Srinivasan K. Ginger rhizomes (Zingiber officinale): A spice with multiple health beneficial potentials // PharmaNutrition. 2017. Vol. 5, Issue 1. P. 18-28. doi: http://doi.org/10.1016/j.phanu.2017.01.001

8. European Pharmacopoeia. 9th ed. Strasbourg: Council of Europe, 2016. 1367 p.

9. Antioxidant activity and phenolic compounds of ginger (Zingiber officinale Rosc.) determined by HPLC-MS/MS / Tohma H., Gülçin İ., Bursal E., Gören A. C., Alwasel S. H., Köksal E. // Journal of Food Measurement and Characterization. 2016. Vol. 11, Issue 2. P. 556-566. doi: http://doi.org/10.1007/s11694-016-9423-Z 
10. Nile S. H., Park S. W. Chromatographic analysis, antioxidant, anti-inflammatory, and xanthine oxidase inhibitory activities of ginger extracts and its reference compounds // Industrial Crops and Products. 2015. Vol. 70. P. 238-244. doi: http://doi.org/10.1016/j.indcrop.2015.03.033

11. Phytochemical Analysis and in vitro Antioxidant Activity of Zingiber officinale / Amir M., Khan A., Mujeeb M., Ahmad A., Usmani S., Akhtar M. // Free Radicals and Antioxidants. 2011. Vol. 1, Issue 4. P. 75-81. doi: http://doi.org/10.5530/ax.2011.4.12

Дата надходження рукопису 28.03.2019

Raimonda Jazokaite, Postgraduate Student, Department of Analytical and Toxicological Chemistry, Lithuanian University of Health Sciences, Sukilèlių str., 13, Kaunas, Lithuania, 50162

E-mail: raimonda0330@gmail.com

Mindaugas Marksa, Lecturer, Department of Analytical and Toxicological Chemistry, Lithuanian University of Health Sciences, Sukilèlių str., 13, Kaunas, Lithuania, 50162

E-mail: minzedas@gmail.com

Augusta Zevzikoviene, PhD, Associate Professor, Department of Analytical and Toxicological Chemistry, Lithuanian University of Health Sciences, Sukilèlių str., 13, Kaunas, Lithuania, 50162

E-mail: augustazev@gmail.com

Andrejus Zevzikovas, PhD, Professor, Department of Analytical and Toxicological Chemistry, Lithuanian University of Health Sciences, Sukilèlių str., 13, Kaunas, Lithuania, 50162

E-mail: andrejuszevzikovas@gmail.com 